\title{
The clinical aspects of pituitary tumour genetics
}

\author{
Judit Dénes ${ }^{1} \cdot$ Márta Korbonits $\mathbb{1}^{2}$
}

Received: 7 November 2020 / Accepted: 16 January 2021 / Published online: 4 February 2021

(c) The Author(s) 2021

\begin{abstract}
Background Pituitary tumours are usually benign and relatively common intracranial tumours, with under- and overexpression of pituitary hormones and local mass effects causing considerable morbidity and increased mortality. While most pituitary tumours are sporadic, around 5\% of the cases arise in a familial setting, either isolated [familial isolated pituitary adenoma, related to AIP or X-linked acrogigantism], or in a syndromic disorder, such as multiple endocrine neoplasia type 1 or 4, Carney complex, McCune-Albright syndrome, phaeochromocytoma/paraganglioma with pituitary adenoma, DICER1 syndrome, Lynch syndrome, and USP8-related syndrome. Genetically determined pituitary tumours usually present at younger age and show aggressive behaviour, and are often resistant to different treatment modalities.

Subject In this practical summary, we take a practical approach: which genetic syndromes should be considered in case of different presentation, such as tumour type, family history, age of onset and additional clinical features of the patient.

Conclusion The identification of the causative mutation allows genetic and clinical screening of relatives at risk, resulting in earlier diagnosis, a better therapeutic response and ultimately to better long-term outcomes.
\end{abstract}

Keywords Pituitary $\cdot$ Tumour $\cdot$ Genetics $\cdot$ FIPA $\cdot$ MEN

\section{Introduction}

Consideration of genetic abnormalities in a patient with a pituitary tumour has only recently entered the clinical thinking of the practising endocrinologist. While in families with multiple endocrine neoplasia type 1 (MEN1) syndrome it was long recognised that members can develop pituitary adenomas with incomplete penetrance, the flurry of conditions we can now list with a genetic cause of pituitary adenoma would have been well beyond imagination 20 years ago. Indeed, most pituitary tumours are sporadic, but approximately $5 \%$ can be due to a hereditary disease. Pituitary tumours can occur in a familial setting, either isolated [Familial Isolated Pituitary Adenoma (FIPA), for example aryl hydrocarbon receptor-interacting protein $(A I P)$

Márta Korbonits

m.korbonits@qmul.ac.uk

1 Divison of Endocrinology, 2nd Department of Medicine, Health Center, Hungarian Defence Forces, Budapest, Hungary

2 Centre for Endocrinology, William Harvey Research Institute, Barts and the London School of Medicine, Queen Mary University of London, London, UK mutation-positive FIPA, or in patients with X-linked acrogigantism (XLAG)], or as part of a syndromic condition, such as MEN1 or MEN4, Carney complex (CNC), McCune-Albright syndrome (MAS), phaeochromocytoma/ paraganglioma with pituitary adenoma ( $3 P$ associations, 3Pa), DICER1 syndrome and a USP8-related syndrome and some other rare conditions where the nature of association with pituitary adenomas needs further studies (Table 1).

Genetic testing might lead to the recognition of a syndromic disease and therefore beneficial effects of timely identification of other aspects of the disease, or it can diagnose disease in family members at an early stage leading to earlier diagnosis and treatment, and ultimately to better outcomes.

Here we approach this issue from the practical point of view, centring the discussion on the presentation of the patient.

\section{Gigantism}

The most common cause of a germline genetic abnormality in a patient with a pituitary adenoma is growth hormone (GH) excess, especially childhood-onset GH excess leading to gigantism. While the usual cause of acromegalic gigantism is a GH-secreting pituitary adenoma, resulting in 
Table 1 Genetic alterations in pituitary tumours

\begin{tabular}{|c|c|c|c|c|}
\hline & Abnormality & Germline & $\begin{array}{l}\text { Mosaic } \\
\text { mutation }\end{array}$ & $\begin{array}{l}\text { Somatic } \\
\text { (tumour only) }\end{array}$ \\
\hline \multirow{3}{*}{ Isolated } & $A I P$ & $x$ & & \\
\hline & GPR101 & $x$ & $x$ & \\
\hline & $\begin{array}{l}\text { Unknown } \\
\text { germline } \\
\text { alterations gene } \\
\text { (s) in AIP- } \\
\text { negative FIPA }\end{array}$ & $x$ & & \\
\hline \multirow[t]{12}{*}{ Syndromic } & $\begin{array}{l}M E N 1, \\
C D K N 1 B, \\
C D C 73^{\mathrm{a}}\end{array}$ & $x$ & $x$ & \\
\hline & $\begin{array}{l}\text { PRKARIA, } \\
\text { PRKACB }^{\mathrm{a}}\end{array}$ & $x$ & & \\
\hline & $S D H x$ & $x$ & & $x$ \\
\hline & $M A X$ & $x$ & & \\
\hline & DICERI & $x$ & & \\
\hline & USP8 & $x^{\mathrm{a}}$ & & $x$ \\
\hline & USP48 & & & $x$ \\
\hline & $M L H, P M S 2$ & $x$ & & \\
\hline & GNAS & & $x$ & $x$ \\
\hline & $V H L$ & $x^{\mathrm{a}}$ & & \\
\hline & $R E T$ & $x^{\mathrm{a}}$ & & \\
\hline & TSC1 & $x^{\mathrm{a}}$ & & \\
\hline \multirow[t]{2}{*}{ Somatic } & $S F 3 B 1$ & & & $x$ \\
\hline & $A T R X$ & & & $x$ \\
\hline
\end{tabular}

${ }^{\mathrm{a}}$ Case reports/further study needed.

elevated $\mathrm{GH}$ - and insulin-like growth factor 1 (IGF-1) levels, we should remember other conditions with tall stature, either as a normal variant or part of a syndrome with no abnormalities in the GH axis [1].

For true acromegalic gigantism we need to consider the age of onset of rapid growth. In case of very early onset, XLAG ( $<2$ years of age) and MAS (from 3 years of age) might be the diagnosis.

XLAG is an infant-onset gigantism syndrome caused by germline or somatic mosaic duplication of the GPR101 gene, which encodes a G-protein coupled receptor [2, 3]. The onset of accelerated growth is always observed before the age of 5 years, and in most patients during the first year of life. Apart from rapid growth, these children have acromegalic features, such as acral enlargement and facial coarsening and other abnormalities, like increased appetite and hyperinsulinemia [4]. Their pituitary MRI can show a tumour, a diffusely enlarged gland suggesting hyperplasia or a normal MRI. The tumours often have an unusual histological appearance (sinusoidal, lobular and acinar architecture, microcalcification and pseudofollicles are characteristic), while hyperplasia can be seen on histology in some cases [3]. Pituitary hyperplasia can be also observed in same cases of MAS, CNC and in GH-releasing hormone (GHRH)-induced GH excess. GPR101 variants, other than gene duplication, have not been associated with $\mathrm{GH}$-secreting or other type of pituitary tumours $[3,5-8]$.

AIP-related gigantism is the most common genetic cause of pituitary gigantism [3, 9]. Patients typically show signs of the disease during the second decade but several cases have been described with accelerated growth already in the first decade. These patients usually have large invasive tumours needing multiple treatment modalities [10, 11], although microadenoma cured after surgery has also been described [12]. Pituitary apoplexy is a characteristic phenomenon in some AIP mutation-positive patients [11-13]. Male predominance is observed in AIP mutation-positive gigantism, although the physiologically later puberty and ascertainment bias due to taller stature in males could play a part in this.

MEN1 syndrome extremely rarely manifests as gigantism. A 5-year-old boy was described with a mammosomatotroph macroadenoma causing gigantism [14], while another case of MEN1-related gigantism was due to a pancreatic GHRH-secreting tumour [15].

MAS is a mosaic disease, caused by a mutation in the GNAS gene at an early post-zygotic stage of development. The variable phenotype depends on what tissues are affected by the mutation. MAS is characterised by fibrous dysplasia, cafè-au-lait spots of the skin and different endocrinopathies. Acromegaly affects around $20 \%$ of MAS patient. The mean age at diagnosis of acromegaly is 24.4 years; however, the disease can start in early childhood as well [16].

In the case of disease onset at $>3$ years of age but still in childhood, AIP, MEN1 and 4, CNC, MAS, 3Pa and a nonpituitary condition neurofibromatosis type 1 (NF1), should be considered. In NF1, approximately $10 \%$ of cases with optic glioma have GH excess often manifesting in childhood and causing accelerated growth; the exact mechanism of the GH excess is unknown (Fig. 1).

\section{Acromegaly}

Apart from age of onset, the other major significant feature for $\mathrm{GH}$ excess patients is the family history. A positive family history is very suggestive of a genetic disease, but we should be aware of phenocopies-the same phenotype by chance and not due to common genetic background; this has been described in several $A I P$ - and succinate dehydrogenase (SDHx)-positive families already [17-19]. In the case of a positive family history, the most common diseases are related to AIP or MEN1 mutations. If there is no family history of pituitary tumours, this could be due to (i) a lack of genetic 
Fig. 1 Diseases to be considered in cases of gigantism. AIP aryl hydrocarbon receptor-interacting protein, AIPneg-FIPA AIP mutation-negative Familial Isolated Pituitary Adenoma (this group does not represent XLAG families), CNC Carney complex, GHRH growth hormonereleasing hormone, MAS McCune-Albright syndrome, MEN multiple endocrine neoplasia, NF1 neurofibromatosis type 1 , TSC tuberous sclerosis, VHL von Hippel-Lindau syndrome, XLAG X-linked acrogigantism. *Case reports/further study needed [69]

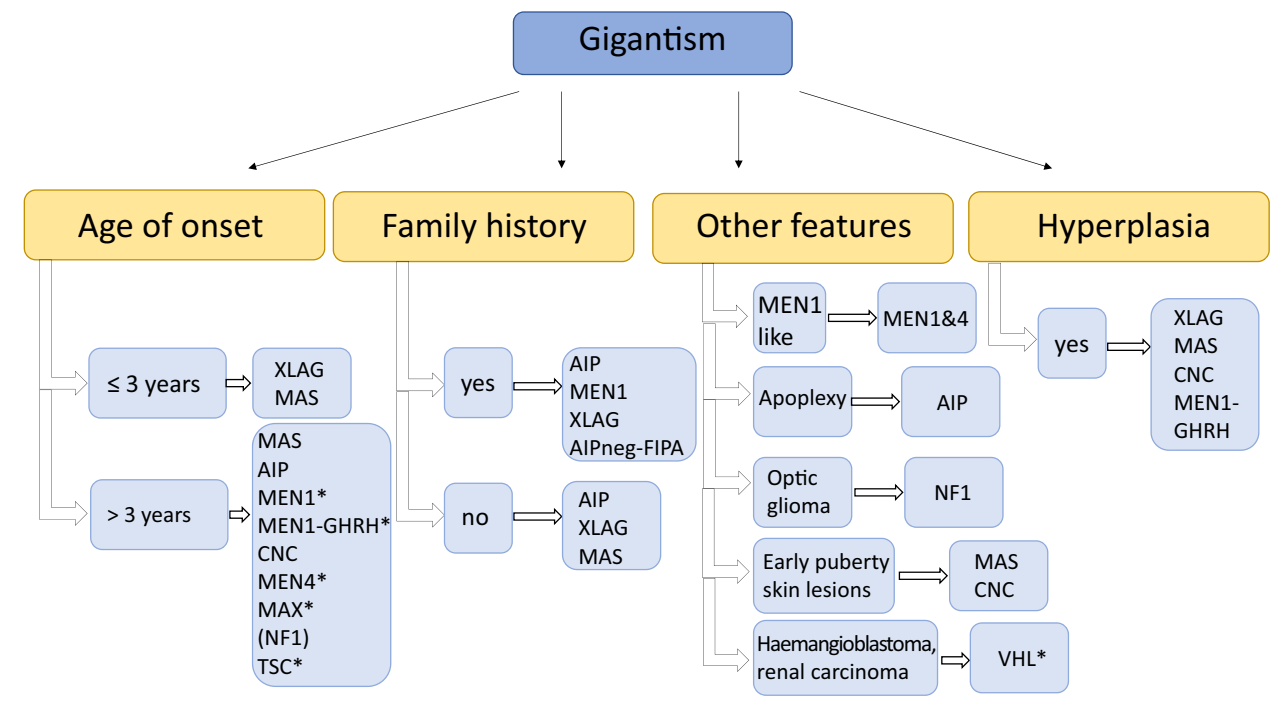

background, (ii) low penetrance, (iii) lack of information regarding a positive family history, (iv) a de novo germline or mosaic mutation and (v) imprinting complicating penetrance ( $S D H D$ for example).

FIPA is defined as two or more members of a family who develop pituitary adenoma with no other clinical manifestation. In FIPA families, either heterogeneouswith different pituitary tumour subtypes, or homogeneous - the most frequent pituitary adenoma subtypes are somatotrophinomas or prolactinomas. Germline mutations in the AIP gene have been identified in $10 \%$ of FIPA families, while in most cases the causative gene(s) remain unknown. It is important to note that $A I P$ mutations can also occur in subjects with apparently sporadic early-onset somatotrophinomas or prolactinomas, as a consequence of incomplete penetrance, while de novo mutations are extremely rare. AIP mutation-positive tumours show a distinct phenotype, with younger age at diagnosis (usually age of onset under 30 years), tumour invasiveness and relative resistance to treatment with first-generation somatostatin receptor ligands. AIP mutation-positive patients usually need a multimodal therapeutic approach. In AIP mutation-negative patients somatotrophinoma is also the most common subtype (although not as common as in AIP mutation-positive subjects, around 78\% compared to $58 \%$ ) [10, 12, 18].

MEN1 is an autosomal dominantly inherited disease characterised by hyperparathyroidism, gastro-enteropancreatic neuroendocrine (NET) and pituitary tumours, with associated other endocrine and non-endocrine tumours. Mutations of the MEN1 tumour suppressor gene are detected in $90 \%$ patients with the MEN1 phenotype. De novo germline or mosaic mutations occur in approximately $10 \%$ of cases. A pituitary tumour develops in $30-40 \%$ of the patients [20]. Prolactinomas are the most common clinically presenting pituitary tumour subtype, sometimes large and arising at a younger age. Patients with MEN1 may have plurihormonal adenomas. Non-functioning pituitary adenomas (NFPAs), somatotrophinomas and, rarely, corticotrophinomas or thyrotrophinomas have also been described. However, during systematic screening of MEN1 mutation carriers, small nonfunctioning lesions, not dissimilar to incidentalomas, can often be found.

Around $10 \%$ of cases with a MEN1-like syndrome do not have a mutation in MEN1. Some of these patients harbour germline changes in the $C D K N 1 B$ gene coding for the cyclin-dependent kinase inhibitor p27. This clinically overlapping rare condition is termed MEN4 [21, 22]. In a group of 24 patients with acromegaly and at least one other manifestation of MEN1 syndrome, but without pathogenic $M E N 1$ or $C D K N 1 B$ variants, a $C D C 73$ missense mutation was found in one case [23].

In cases of the MEN1 syndrome, a GHRH-secreting pancreatic [24] or thymic [25] NET tumour might be part of the syndrome and the source of GHRH, which causes pituitary hyperplasia and thus acromegaly. A similar case has now been described in a patient with germline $M A X$ mutation and multiple tumours including a GHRH-positive phaeochromocytoma [26].

$\mathrm{CNC}$ is a clinical diagnosis based on characteristic skin pigmentation, cardiac myxomas, primary pigmented nodular adrenocortical disease and pituitary tumour or hyperplasia, testicular lesions, melanotic schwannomas and others. Although around $75 \%$ of patients have an abnormal $\mathrm{GH}$ axis in CNC, only $10 \%$ of the patients show clinically acromegaly, and less frequently gigantism. Most patients (67\%) have pituitary hyperplasia affecting the somatolactotroph cells, while only $10-12 \%$ of them have a real GH-producing pituitary tumour [27]. Genetic testing for inactivating germline mutations in the protein kinase A 


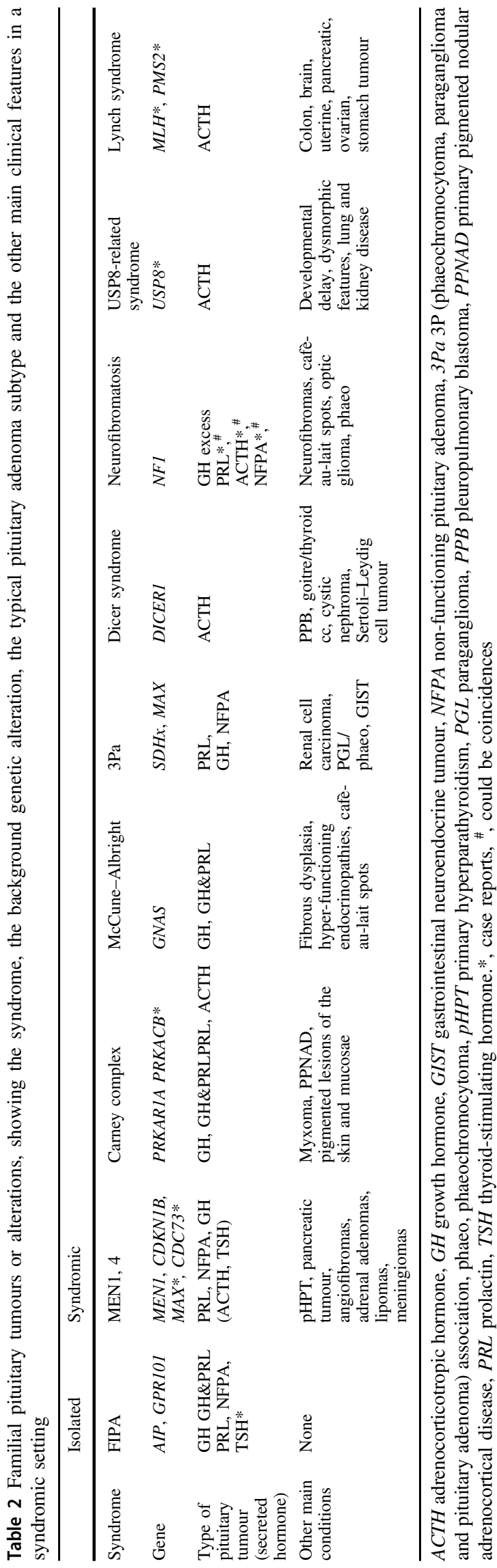

regulatory subunit $1-\alpha(P R K A R 1 A)$ coding gene is available, and large deletions are known to cause more severe disease. There is a second locus located at $2 \mathrm{p} 16$, which is still unknown, but cytogenetic changes of the 2 p16 chromosomal region are frequently observed in tumours from CNC patients [28, 29].

Phaeochromocytoma/paraganglioma can be associated with pituitary tumours (the $3 \mathrm{~Pa}$ ), even carcinoma [30], due to mutations in $S D H x$ or $M A X$ genes. The pituitary tumours include somatotrophinomas, prolactinomas and NFPAs. Recently MAX mutation has been described in families with phaeochromocytoma, pituitary adenoma and other endocrine- and non-endocrine tumours [26]. Acromegaly associated with phaeochromocytoma can be the consequence of a GHRH-secreting phaeochromocytoma without any pituitary adenoma $[19,31]$ (Table 2).

NF1-associated GH excess should be considered in patients with characteristic clinical signs and symptoms of dermal neurofibromas, café-au-lait spots, axillary or inguinal freckling and hamartomas of the iris as well as brain neoplasms due to inactivating mutation of $N F 1$ gene. Around $10 \%$ of children with NF1 and optic pathways glioma show GH excess [32]. While tuberous sclerosis has been described with pituitary adenomas, the causative link between the two diseases is uncertain $[33,34]$.

Acromegalic features and GH hypersecretion have been recently described in patients with mutations in the X-linked immunoglobulin superfamily member 1 (IGSF1) gene. The exact mechanism of GH excess is unclear [35].

Somatic mutations can lead to acromegaly as well. The most frequent genetic alteration is somatic GNAS mutation, found in $40 \%$ of somatotrophinomas [36]. These tumours show favourable clinical features, such as older age at diagnosis, less invasiveness and better response to therapy (Fig. 2).

\section{Prolactinoma}

Prolactinomas are the most common pituitary adenoma subtype in MEN1, and the second most common in MEN4 and FIPA, both in AIP-positive (even as a homogenous prolactinoma family [37]) and $A I P$-negative FIPA, but can occur in $S D H x$ cases as well (Fig. 3). Metastatic prolactinoma case has been described in MEN1 [38]. A large childhood-onset prolactinoma can be the first manifestation of MEN1 or AIP-related disease. Recently, two families with $M A X$ mutations with multiple tumour types were described, including a patient with prolactinoma and parathyroid tumour in one of them [26].

Recently, a somatic mutation in the $S F 3 B 1$ gene has been described in $20 \%$ of prolactinoma patients, showing higher prolactin (PRL) levels [39]. 
Fig. 2 Diseases to be considered in cases of acromegaly. AIP aryl hydrocarbon receptor-interacting protein, AIPneg-FIPA AIP mutation-negative Familial Isolated Pituitary Adenoma (this group does not represent XLAG families), CNC Carney complex, FIPA Familial Isolated Pituitary Adenoma, GH growth hormone, GHRH growth hormonereleasing hormone, MEN multiple endocrine neoplasia, NET neuroendocrine tumour, phaeo phaeochromocytoma, SDH succinate dehydrogenase. *Case reports/further study needed $[25,70]$

Fig. 3 Diseases to be considered in cases of prolactinoma. AIP aryl hydrocarbon receptorinteracting protein, AIPnegFIPA AIP mutation-negative Familial Isolated Pituitary Adenoma (this group does not represent XLAG families), MEN multiple endocrine neoplasia, NF1 neurofibromatosis type 1 , 3Pa 3P (phaeochromocytoma, paraganglioma and pituitary adenoma) association, SDH succinate dehydrogenase. *Case reports/further study needed [45]
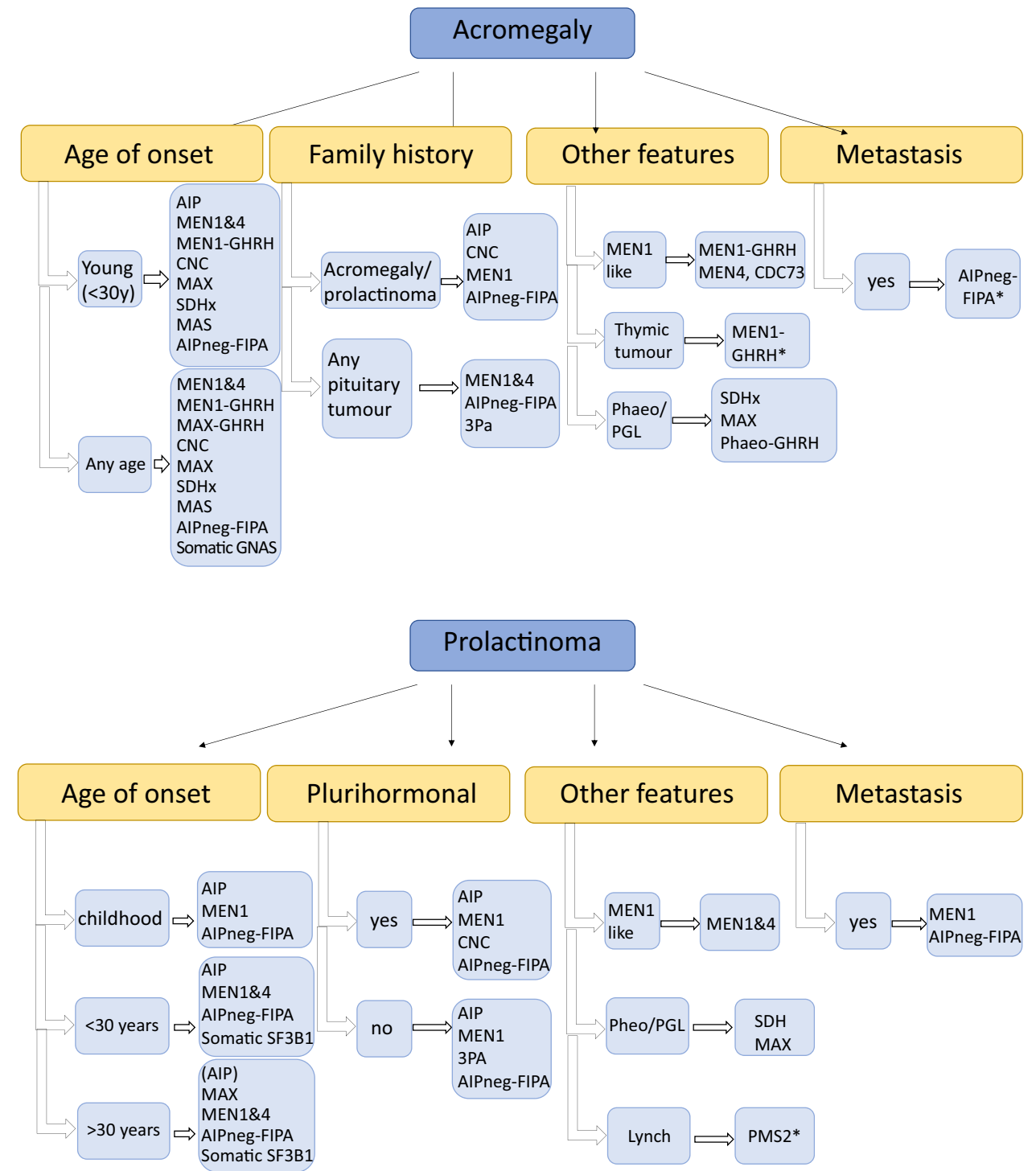

\section{Cushing's disease}

Infant-onset Cushing's disease can occur in DICER1 syndrome with very low penetrance due to a pituitary blastoma, but this is pathognomic to the disease. Pituitary blastomas are aggressive tumours arising in young children, presenting clinically with often severe ACTH-dependent hypercortisolism. It is locally destructive, severe disease with high mortality [40]. A family history of young-onset large goitre, pleuropulmonary blastoma, Sertoli-Leydig cell tumours, nodular thyroid hyperplasia or differentiated cancer of the thyroid, cystic nephroma and renal sarcoma can be associated [41]. Cushing's disease is rare $(5-10 \%)$ in MEN1 [42], and to date no convincing AIP mutationpositive patient has been found with a corticotrophinoma. More recently, a few cases of $C D K N 1 B$ mutations were described in children with corticotrophinoma with or without other features of MEN4 [43]. Germline potentially pathogenic CABLES1 variants were identified in $2 \%$ of the cases in a patient cohort of Cushing's disease [44]. Aggressively growing corticotroph tumours has been described as part of Lynch syndrome in patients with DNA mismatch repair genes MSH6, PMS2 mutations and associated colorectal, endometrial, ovarian, urinary tract, small bowel, gastric, hepatobiliary, adrenocortical or malignant brain tumours [45]. Cushing's disease has been described in patients with RET mutation as part of MEN2A or MEN2B syndrome. It is unclear whether these cases are coincidences, or RET mutation plays a causative role in pituitary tumour formation ([46, 47] and references within [19]).

Somatic USP8 mutations can be observed in corticotrophinomas in a high (around 30\%) percentage. Patients harbouring mutations in this gene are predominantly 
female, and they have more frequently microadenomas with better therapeutic outcome [48, 49]. Germline USP8 mutation has been found in a paediatric case with recurrent Cushing's disease and developmental delay, representing a syndromic form of pituitary adenomas [50]. Somatic GNAS mutation might occur very rarely in ACTH-producing pituitary adenomas [51, 52]. The differential diagnosis of Cushing's syndrome is often challenging, but two recent case reports complicated this further in CNC: in addition to the typical adrenal Cushing's syndrome, pituitary Cushing's disease have been also described [53, 54]. Recently aggressive corticotroph pituitary tumours and carcinomas harbouring somatic mutations in ATRX [55] have been described (Table 2) (Fig. 4).

\section{Non-functioning pituitary adenoma}

NFPAs can occur in MEN1 and mostly AIP mutationnegative FIPA patients. NFPA can be part of AIP mutationnegative homogenous NFPA kindreds-12\% in our cohort of 318 FIPA kindreds, or part of heterogenous families$31 \%$ in our AIP mutation-negative cohort. AIP mutationpositive clinically NFPA cases are often microadenomas identified in asymptomatic carriers or if operated show positive GH and PRL immunostaining [56]. NFPA might be part of the $3 \mathrm{~Pa}$ as well, and interestingly, the pituitary carcinoma case with an $S D H B$ mutation was a non-functioning pituitary tumour [30]. NFPAs are most often clinically silent tumours, most often of gonadotroph origin (Fig. 5).

\section{Thyrotrophinoma}

TSH-producing pituitary tumours are very rare in a familial setting. There is one case described with an AIP mutation and a few cases with MEN1 mutation [57] including an MEN1 mutation-positive metastatic case [58]. In MEN1 syndrome PIT1-positive plurihormonal adenomas can also be identified, sometimes with silent or clinically relevant TSH positivity [59-61]. Somatic mutation has been described in TR $\beta$ (THRB) [62] and a patient with TSHoma and germline THRB mutation [63], corresponding to data from a THRB-deficiency animal model where TSHsecreting adenomas have been observed [64] (Fig. 6).

\section{Clinical considerations}

Pituitary tumours in a familial setting are relatively rare disorders, and identification of the genetic cause can lead to several advantages. Discovery of a syndromic disease might help to identify other aspects of the proband's condition with beneficial effects through earlier treatment. Genetic screening might help to identify family members in an earlier stage of the disease, when the tumour responds better to therapy and a better outcome can predicted.

First of all, a detailed family history should be obtained from all patients with a pituitary tumour. In case of FIPA, screening for AIP mutations should be considered, as mutations are identified in about $10 \%$ of unselected families and $20 \%$ of those with familial acromegaly. Screening for AIP mutations should also be considered in patients, primarily with $\mathrm{GH}$ or prolactin-secreting adenomas, with age at onset $\leq 18$ years and patients with macroadenomas and age at onset $\leq 30$ years. Genetic and clinical screening show clear benefits in AIP mutation-positive patients; prospectively diagnosed patients have smaller, less invasive lesions controlled less frequently with multimodal treatment, compared with clinically presenting patients [65]. XLAG should also be considered in case of early-onset gigantism starting during the first 2 years of life.

In the case of MEN1, the additional main clinical features, such as hyperparathyroidism and enteropancreatic NET present in the proband or other family members, can help in the decision regarding genetic testing. However, pituitary tumours may represent the first disease manifestation, and considering the possibility of de novo mutations, screening for MEN1 should be considered in patients with childhood-onset pituitary macroadenomas (especially prolactinomas) [66]. In patients with a MEN1 phenotype but without MEN1 mutation, the rare MEN4 should be considered and genetic testing for $C D K N 1 B$ mutation is suggested. Case reports of patients with multiple endocrine tumours and $C D C 73$ or $M A X$ variants have been described.

Other less frequent syndromes should be considered in the presence of associated features, such as testing for $S D H x$ mutation in case of phaeochromocytoma/paraganglioma with pituitary adenoma or testing for PRKARIA in case of symptoms characteristic of CNC.

For patients with pituitary diseases there are a few questions to consider:

\section{- Which patient needs genetic testing?}

Genetic testing is recommended in patients (i) with a family history of pituitary tumour, (ii) with early-onset pituitary tumour and (iii) with additional clinical features which predispose to pituitary tumour in a syndromic setting.

- What change will bring a genetic diagnosis in the treatment or the follow-up of the proband?

Identifying a mutation helps to understand the nature of the disease and be more vigilant regarding tumour behaviour, can draw attention to possible hyperplasia, but in general would not necessarily change the treatment algorithm of the proband.

- Which family members need genetic screening? Genetic testing should be offered to first-degree 
Fig. 4 Diseases to be considered in cases of Cushing's disease. AIP aryl hydrocarbon receptorinteracting protein, AIPnegFIPA AIP mutation-negative Familial Isolated Pituitary Adenoma (this group does not represent XLAG families), CDKN1B cyclin-dependent kinase inhibitor $1 \mathrm{~B}, \mathrm{CNC}$ Carney complex, FIPA Familial Isolated Pituitary Adenoma, TSC tuberous sclerosis. ${ }^{*}$ Case reports/further study needed [19, 45-47, 50, 52-54, 71-73]
Fig. 5 Diseases to be considered in cases of non-functioning pituitary adenoma (NFPA). AIP aryl hydrocarbon receptorinteracting protein, AIPnegFIPA AIP mutation-negative Familial Isolated Pituitary Adenoma (this group does not represent XLAG families), FIPA Familial Isolated Pituitary Adenoma, GH growth hormone, MEN multiple endocrine neoplasia, PRL prolactin, SDH succinate dehydrogenase. ${ }^{*}$ Case reports/further study needed $[45,74]$
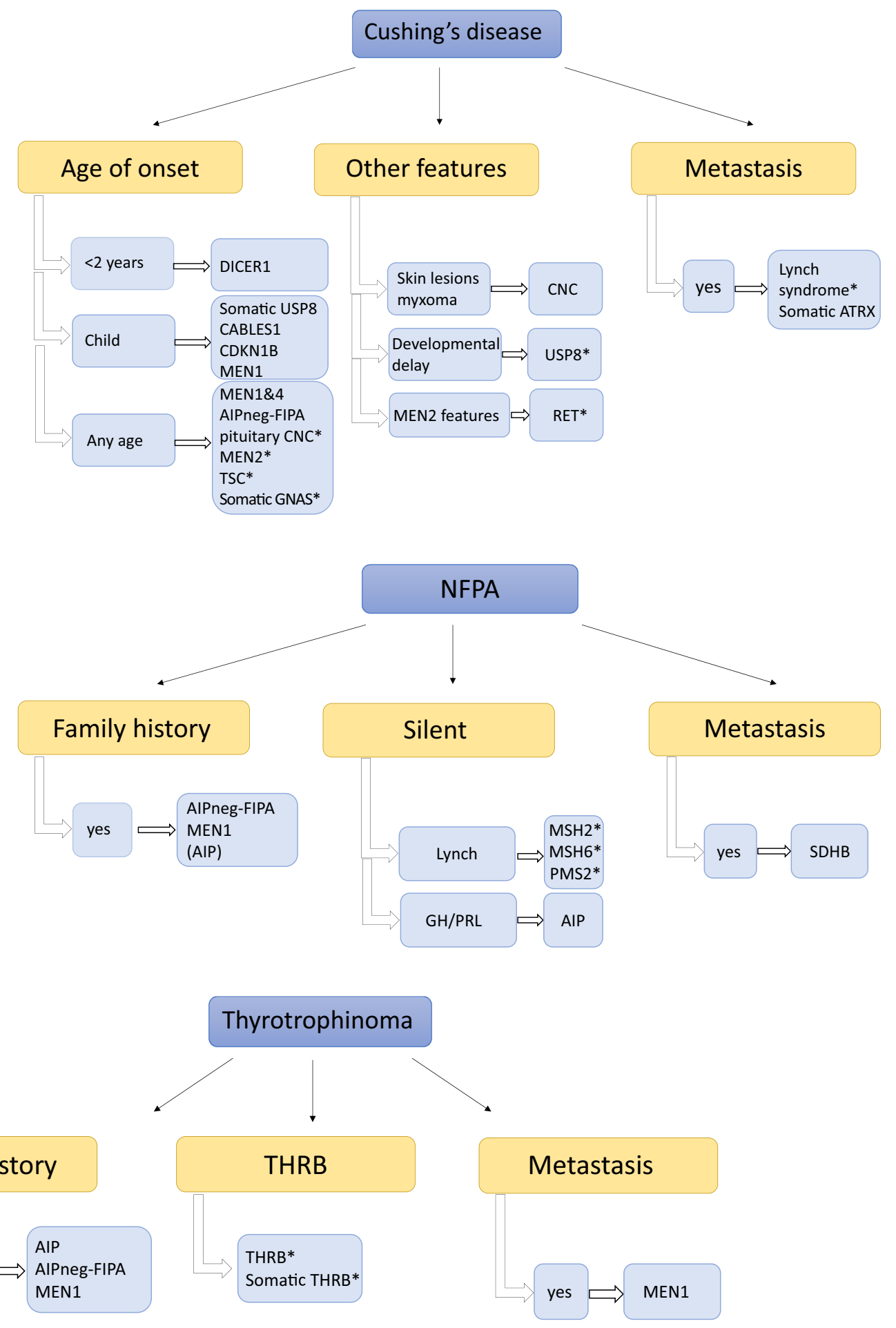

Fig. 6 Diseases to be considered in cases of thyrotrophinomas. AIP aryl hydrocarbon receptor-interacting protein, AIPneg-FIPA AIP mutation-negative Familial Isolated Pituitary Adenoma (this group does not represent XLAG families), FIPA Familial Isolated Pituitary Adenoma, MEN multiple endocrine neoplasia, THRB thyroid hormone receptor beta. ${ }^{*}$ Case reports/further study needed $[62,63]$ relatives (children, siblings and parents) of a gene carrier.

- How should carrier family members be followed up? It depends on the specific syndromic condition, but in general baseline clinical, biochemical and imaging assessment is needed with follow-up depending on the specific syndrome and patient age.

In the case of $A I P$ mutation carriers, it is advised to 
monitor growth starting in early childhood and yearly biochemical testing (GH, IGF-1 and prolactin) not later than at the age of 10 years. A baseline pituitary MRI is advised around the age of 10 and should be repeated every 5 years until the age of 30 , although between 20 and 30 follow-up could be gradually relaxed to facilitate patient cooperation. In carriers identified as adults, if a baseline clinical and biochemical assessments with pituitary MRI has not identified any abnormality, then screening can be reduced after the age of 30, as most patients with AIP mutation start their disease before this age.

In case of MEN1 patients, published guidelines should be followed. For pituitary disease, starting at the age of 5 with yearly clinical and biochemical assessments (prolactin and IGF-1). A pituitary MRI should be performed every 3 years [67, 68].

- If the categorisation of an identified variant is unclear, i.e., a variant of uncertain significance, what policy should be followed for the proband and family members?

In this case, genetic testing of family members is not recommended. However, attention should be focused on any family member developing typical signs or symptoms; that person should be clinically evaluated, and if affected, genetic testing performed. As data on genetic variants are constantly evolving, patients and their clinicians should be later notified if the status of the variant has changed based on novel clinical, experimental or genetic data.

In conclusion, genetic testing not only helps us to identify patients with an increased risk of developing pituitary or other tumours, and to achieve early diagnosis and better therapeutic outcome, but also leads to better understanding of pituitary tumorigenesis.

\section{Compliance with ethical standards}

Conflict of interest The authors declare that they have no conflict of interest.

Publisher's note Springer Nature remains neutral with regard to jurisdictional claims in published maps and institutional affiliations.

Open Access This article is licensed under a Creative Commons Attribution 4.0 International License, which permits use, sharing, adaptation, distribution and reproduction in any medium or format, as long as you give appropriate credit to the original author(s) and the source, provide a link to the Creative Commons license, and indicate if changes were made. The images or other third party material in this article are included in the article's Creative Commons license, unless indicated otherwise in a credit line to the material. If material is not included in the article's Creative Commons license and your intended use is not permitted by statutory regulation or exceeds the permitted use, you will need to obtain permission directly from the copyright holder. To view a copy of this license, visit http://creativecommons. org/licenses/by/4.0/.

\section{References}

1. P. Marques, M. Korbonits, Pseudoacromegaly. Front. Neuroendocrinol. 52, 113-143 (2019). https://doi.org/10.1016/j.yfrne. 2018.11.001

2. G. Trivellin, A. Daly, F. Faucz, B. Yuan, L. Rostomyan, D. Larco, M. Schernthaner-Reiter, E. Szarek, L. Leal, J.H. Caberg, E. Castermans, C. Villa, A. Dimopoulos, P. Chittiboina, P. Xekouki, N. Shah, D. Metzger, P. Lysy, E. Ferrante, N. Strebkova, N. Mazerkina, M. Zatelli, M. Lodish, A. Horvath, R.B. de Alexandre, A. Manning, I. Levy, M. Keil, M. de la Luz Sierra, L. Palmeira, W. Coppieters, M. Georges, L. Naves, M. Jamar, V. Bours, T. Wu, C. Choong, J. Bertherat, P. Chanson, P. Kamenický, W. Farrell, A. Barlier, M. Quezado, I. Bjelobaba, S. Stojilkovic, J. Wess, S. Costanzi, P. Liu, J. Lupski, A. Beckers, C. Stratakis, Gigantism and acromegaly due to Xq26 microduplications and GPR101 mutation. N. Engl. J. Med. 371(25), 2363-2374 (2014). https://doi.org/10.1056/NEJMoa1408028

3. D. Iacovazzo, R. Caswell, B. Bunce, S. Jose, B. Yuan, L.C. Hernández-Ramírez, S. Kapur, F. Caimari, J. Evanson, F. Ferraù, M.N. Dang, P. Gabrovska, S.J. Larkin, O. Ansorge, C. Rodd, M. L. Vance, C. Ramírez-Renteria, M. Mercado, A.P. Goldstone, M. Buchfelder, C.P. Burren, A. Gurlek, P. Dutta, C.S. Choong, T. Cheetham, G. Trivellin, C.A. Stratakis, M.B. Lopes, A.B. Grossman, J. Trouillas, J.R. Lupski, S. Ellard, J.R. Sampson, F. Roncaroli, M. Korbonits, Germline or somatic GPR101 duplication leads to X-linked acrogigantism: a clinico-pathological and genetic study. Acta Neuropathol. Commun. 4 (2016). https://doi. org/10.1186/s40478-016-0328-1

4. A. Beckers, M.B. Lodish, G. Trivellin, L. Rostomyan, M. Lee, F. R. Faucz, B. Yuan, C.S. Choong, J.H. Caberg, E. Verrua, L.A. Naves, T.D. Cheetham, J. Young, P.A. Lysy, P. Petrossians, A. Cotterill, N.S. Shah, D. Metzger, E. Castermans, M.R. Ambrosio, C. Villa, N. Strebkova, N. Mazerkina, S. Gaillard, G.B. Barra, L. A. Casulari, S.J. Neggers, R. Salvatori, M.L. Jaffrain-Rea, M. Zacharin, B.L. Santamaria, S. Zacharieva, E.M. Lim, G. Mantovani, M.C. Zatelli, M.T. Collins, J.F. Bonneville, M. Quezado, P. Chittiboina, E.H. Oldfield, V. Bours, P. Liu, W. De Herder, N. Pellegata, J.R. Lupski, A.F. Daly, C.A. Stratakis, X-linked acrogigantism (X-LAG) syndrome: clinical profile and therapeutic responses. Endocr. Relat. Cancer 22(3), 353-367 (2015). https:// doi.org/10.1530/erc-15-0038

5. A.L. Lecoq, J. Bouligand, M. Hage, L. Cazabat, S. Salenave, A. Linglart, J. Young, A. Guiochon-Mantel, P. Chanson, P. Kamenický, Very low frequency of germline GPR101 genetic variation and no biallelic defects with AIP in a large cohort of patients with sporadic pituitary adenomas. Eur. J. Endocrinol. 174(4), 523-530 (2016). https://doi.org/10.1530/eje-15-1044

6. F. Ferraù, P.D. Romeo, S. Puglisi, M. Ragonese, M.L. Torre, C. Scaroni, G. Occhi, E. De Menis, G. Arnaldi, F. Trimarchi, S. Cannavò, Analysis of GPR101 and AIP genes mutations in acromegaly: a multicentric study. Endocrine 54(3), 762-767 (2016). https://doi.org/10.1007/s12020-016-0862-4

7. R. Matsumoto, M. Izawa, H. Fukuoka, G. Iguchi, Y. Odake, K. Yoshida, H. Bando, K. Suda, H. Nishizawa, M. Takahashi, N. Inoshita, S. Yamada, W. Ogawa, Y. Takahashi, Genetic and clinical characteristics of Japanese patients with sporadic somatotropinoma. Endocr. J. 63(11), 953-963 (2016). https://doi.org/ 10.1507/endocrj.EJ16-0075

8. G. Trivellin, R.R. Correa, M. Batsis, F.R. Faucz, P. Chittiboina, I. Bjelobaba, D.O. Larco, M. Quezado, A.F. Daly, S.S. Stojilkovic, T.J. Wu, A. Beckers, M. Lodish, C.A. Stratakis, Screening for GPR101 defects in pediatric pituitary corticotropinomas. Endocr. Relat. Cancer 23(5), 357-365 (2016). https://doi.org/10.1530/erc16-0091 
9. L. Rostomyan, A.F. Daly, P. Petrossians, E. Nachev, A.R. Lila, A. L. Lecoq, B. Lecumberri, G. Trivellin, R. Salvatori, A.G. Moraitis, I. Holdaway, D.J. Kranenburg-van Klaveren, M. Chiara Zatelli, N. Palacios, C. Nozieres, M. Zacharin, T. Ebeling, M. Ojaniemi, L. Rozhinskaya, E. Verrua, M.L. Jaffrain-Rea, S. Filipponi, D. Gusakova, V. Pronin, J. Bertherat, Z. Belaya, I. Ilovayskaya, M. Sahnoun-Fathallah, C. Sievers, G.K. Stalla, E. Castermans, J.H. Caberg, E. Sorkina, R.S. Auriemma, S. Mittal, M. Kareva, P.A. Lysy, P. Emy, E. De Menis, C.S. Choong, G. Mantovani, V. Bours, W. De Herder, T. Brue, A. Barlier, S.J. Neggers, S. Zacharieva, P. Chanson, N.S. Shah, C.A. Stratakis, L. A. Naves, A. Beckers, Clinical and genetic characterization of pituitary gigantism: an international collaborative study in 208 patients. Endocr. Relat. Cancer 22(5), 745-757 (2015). https://doi. org/10.1530/erc-15-0320

10. A.F. Daly, M.A. Tichomirowa, P. Petrossians, E. Heliövaara, M. L. Jaffrain-Rea, A. Barlier, L.A. Naves, T. Ebeling, A. Karhu, A. Raappana, L. Cazabat, E. De Menis, C.F. Montañana, G. Raverot, R.J. Weil, T. Sane, D. Maiter, S. Neggers, M. Yaneva, A. Tabarin, E. Verrua, E. Eloranta, A. Murat, O. Vierimaa, P.I. Salmela, P. Emy, R.A. Toledo, M.I. Sabaté, C. Villa, M. Popelier, R. Salvatori, J. Jennings, A.F. Longás, J.I. Labarta Aizpún, M. Georgitsi, R. Paschke, C. Ronchi, M. Valimaki, C. Saloranta, W. De Herder, R. Cozzi, M. Guitelman, F. Magri, M.S. Lagonigro, G. Halaby, V. Corman, M.T. Hagelstein, J.F. Vanbellinghen, G.B. Barra, A.P. Gimenez-Roqueplo, F.J. Cameron, F. Borson-Chazot, I. Holdaway, S.P. Toledo, G.K. Stalla, A. Spada, S. Zacharieva, J. Bertherat, T. Brue, V. Bours, P. Chanson, L.A. Aaltonen, A. Beckers, Clinical characteristics and therapeutic responses in patients with germ-line AIP mutations and pituitary adenomas: an international collaborative study. J. Clin. Endocrinol. Metab. 95(11), E373-E383 (2010). https://doi.org/10.1210/jc.2009-2556

11. P. Dutta, K.S. Reddy, A. Rai, A.K. Madugundu, H.S. Solanki, A. Bhansali, B.D. Radotra, N. Kumar, D. Collier, D. Iacovazzo, P. Gupta, R. Raja, H. Gowda, A. Pandey, J.S. Devgun, M. Korbonits, Surgery, octreotide, temozolomide, bevacizumab, radiotherapy, and pegvisomant treatment of an AIP mutation-positive child. J. Clin. Endocrinol. Metab. 104(8), 3539-3544 (2019). https://doi.org/10.1210/jc.2019-00432

12. L.C. Hernández-Ramírez, P. Gabrovska, J. Dénes, K. Stals, G. Trivellin, D. Tilley, F. Ferraù, J. Evanson, S. Ellard, A.B. Grossman, F. Roncaroli, M.R. Gadelha, M. Korbonits, A. Agha, S.A. Akker, E.D. Aflorei, S. Alföldi, W. Arlt, B. Atkinson, A. Aulinas-Masó, S.J. Aylwin, P.F. Backeljauw, C. Badiu, S. Baldeweg, G. Bano, A. Barkan, J. Barwell, C. Bernal-González, G.M. Besser, J.S. Bevan, J. Blair, P. Bouloux, L. Bradley, M. Buchfelder, M. Cakir, N. Canham, P. Carroll, H.S. Chahal, T. Cheetham, F. Chentli, R.N. Clayton, M. Cohen, T. Cole, H. Courtney, E. Crowne, D. Cuthbertson, J. Dal, N. Dalantaeva, C. Daousi, K. Darzy, M. Dattani, J.H. Davies, J. Davis, M. De Castro, L. De Marinis, W. Drake, P. Dutta, L. Dzeranova, B. Edén-Engström, R. Eeles, M. Elfving, M. Elston, L. Emmerson, N. Fersht, S. Fica, S. Fischli, D. Flanagan, M. Fleseriu, P.U. Freda, T. Friedman, L.A. Frohman, P. Gallego, E. Gevers, E. Gláz, J.A. Goldman, A.P. Goldstone, M. Goth, L. Greenhalgh, J. Grieve, M. Guitelman, A. Gürlek, M. Gurnell, K. Horvath, T.A. Howlett, C. Höybye, S. Hunter, D. Iacovazzo, P. Igaz, W.J. Inder, T. Iwata, L. Izatt, S. Jagadeesh, G. Kaltsas, F. Kaplan, N. Karavitaki, D. Kastelan, M. Katz, T. Kearney, B. Khoo, C. Kiraly-Borri, R. Knispelis, G.L. Kovács, A.V. Kumar, E.R. Laws, R.M. Lechan, M.J. Levy, K. Lewandowski, J. Lo, N. Maartens, A. Matsuno, B. McGowan, S. E. McQuaid, M. Medic-Stojanoska, M. Mercado-Atri, E. Mezősi, D. Miljic, K.K. Miller, S. Modenesi, M.E. Molitch, J. Monson, D. G. Morris, P.J. Morrison, A. Munir, R.D. Murray, M. Musat, N. Musolino, L. Nachtigall, J. Newell-Price, A. Ogilvie, S.M. Orme, I. Paşcanu, A. Patócs, C. Patterson, S.H. Pearce, F. Pecori Giraldi,
M. Pfeifer, V. Popovic, N. Poplawski, M. Powell, P. Pullan, R. Quinton, S. Radian, H. Randeva, A. Ribeiro-Oliveira, C. Rodd, F. Ryan, R. Salvatori, C. Schöfl, D. Shears, K. Shotliff, B.S. Soares, N. Somasundaram, A. Spada, J. Sperber, H.A. Spoudeas, S. Stewart, H. Storr, C. Strasburger, M.E. Street, F. Swords, R.V. Thakker, E. Tham, C. Thompson, D.M.O. Thorner, M. Tóth, P.J. Trainer, S. Tsagarakis, M. Tzanela, J. Vadász, V. Vaks, R. Verkauskiene, J.A. Wass, S.M. Webb, A. Weber, S. Yamada, S. Yarman, P. Yeoh, K. Yoshimoto, N.N. Zammitt, Landscape of familial isolated and young-onset pituitary adenomas: prospective diagnosis in AIP mutation carriers. J. Clin. Endocrinol. Metab. 100(9), E1242-E1254 (2015). https://doi.org/10.1210/jc.20151869

13. C. Villa, M.S. Lagonigro, F. Magri, M. Koziak, M.L. JaffrainRea, R. Brauner, J. Bouligand, M.P. Junier, F. Di Rocco, C. Sainte-Rose, A. Beckers, F.X. Roux, A.F. Daly, L. Chiovato, Hyperplasia-adenoma sequence in pituitary tumorigenesis related to aryl hydrocarbon receptor interacting protein gene mutation. Endocr. Relat. Cancer 18(3), 347-356 (2011). https://doi.org/10. 1530/erc-11-0059

14. W.E. Farrell, M.F. Azevedo, D.L. Batista, A. Smith, I. Bourdeau, A. Horvath, M. Boguszewski, M. Quezado, C.A. Stratakis, Unique gene expression profile associated with an early-onset multiple endocrine neoplasia (MEN1)-associated pituitary adenoma. J. Clin. Endocrinol. Metab. 96(11), E1905-E1914 (2011). https://doi.org/10.1210/jc.2011-1127

15. V. Srirangam Nadhamuni, D. Iacovazzo, J. Evanson, J. Trouillas, T. Kurzawinski, S. Bhattacharya, M. Korbonits, Unusual cause of gigantism - growth hormone releasing hormone (GHRH)-secreting pancreatic neuroendocrine tumour in a patient with multiple endocrine neoplasia type 1 (MEN1). Endocrine Abstracts 67, O36 (2019)

16. S. Salenave, A.M. Boyce, M.T. Collins, P. Chanson, Acromegaly and McCune-Albright syndrome. J. Clin. Endocrinol. Metab. 99 (6), 1955-1969 (2014). https://doi.org/10.1210/jc.2013-3826

17. S. Igreja, H.S. Chahal, P. King, G.B. Bolger, U. Srirangalingam, L. Guasti, J.P. Chapple, G. Trivellin, M. Gueorguiev, K. Guegan, K. Stals, B. Khoo, A.V. Kumar, S. Ellard, A.B. Grossman, M. Korbonits, Characterization of aryl hydrocarbon receptor interacting protein (AIP) mutations in familial isolated pituitary adenoma families. Hum. Mutat. 31(8), 950-960 (2010). https://doi. org/10.1002/humu.21292

18. O. Vierimaa, M. Georgitsi, R. Lehtonen, P. Vahteristo, A. Kokko, A. Raitila, K. Tuppurainen, T.M. Ebeling, P.I. Salmela, R. Paschke, S. Gündogdu, E. De Menis, M.J. Mäkinen, V. Launonen, A. Karhu, L.A. Aaltonen, Pituitary adenoma predisposition caused by germline mutations in the AIP gene. Science 312(5777), 1228-1230 (2006). https://doi.org/10.1126/science. 1126100

19. J. Dénes, F. Swords, E. Rattenberry, K. Stals, M. Owens, T. Cranston, P. Xekouki, L. Moran, A. Kumar, C. Wassif, N. Fersht, S.E. Baldeweg, D. Morris, S. Lightman, A. Agha, A. Rees, J. Grieve, M. Powell, C.L. Boguszewski, P. Dutta, R.V. Thakker, U. Srirangalingam, C.J. Thompson, M. Druce, C. Higham, J. Davis, R. Eeles, M. Stevenson, B. O'Sullivan, P. Taniere, K. Skordilis, P. Gabrovska, A. Barlier, S.M. Webb, A. Aulinas, W.M. Drake, J.S. Bevan, C. Preda, N. Dalantaeva, A. Ribeiro-Oliveira Jr., I.T. Garcia, G. Yordanova, V. Iotova, J. Evanson, A.B. Grossman, J. Trouillas, S. Ellard, C.A. Stratakis, E.R. Maher, F. Roncaroli, M. Korbonits, Heterogeneous genetic background of the association of pheochromocytoma/paraganglioma and pituitary adenoma: results from a large patient cohort. J. Clin. Endocrinol. Metab. 100 (3), E531-E541 (2015). https://doi.org/10.1210/jc.2014-3399

20. R.V. Thakker, Multiple endocrine neoplasia type 1 (MEN1) and type 4 (MEN4). Mol. Cell Endocrinol. 386(1-2), 2-15 (2014). https://doi.org/10.1016/j.mce.2013.08.002 
21. R. Alrezk, F. Hannah-Shmouni, C.A. Stratakis, MEN4 and CDKN1B mutations: the latest of the MEN syndromes. Endocr. Relat. Cancer 24(10), T195-t208 (2017). https://doi.org/10.1530/ erc-17-0243

22. N.S. Pellegata, L. Quintanilla-Martinez, H. Siggelkow, E. Samson, K. Bink, H. Höfler, F. Fend, J. Graw, M.J. Atkinson, Germline mutations in p27Kip1 cause a multiple endocrine neoplasia syndrome in rats and humans. Proc. Natl Acad. Sci. USA 103(42), 15558-15563 (2006). https://doi.org/10.1073/pnas.0603877103

23. L.B. Nachtigall, F.J. Guarda, K.E. Lines, A. Ghajar, L. Dichtel, G. Mumbach, W. Zhao, X. Zhang, N.A. Tritos, B. Swearingen, K.K. Miller, R.V. Thakker, Clinical MEN-1 among a large cohort of patients with acromegaly. J. Clin. Endocrinol. Metab. 105(6), e2271-e2281 (2020). https://doi.org/10.1210/clinem/dgaa142

24. F. Borson-Chazot, L. Garby, G. Raverot, F. Claustrat, V. Raverot, G. Sassolas, Acromegaly induced by ectopic secretion of GHRH: a review 30 years after GHRH discovery. Ann. Endocrinol. (Paris) 73(6), 497-502 (2012). https://doi.org/10.1016/j.ando.2012.09. 004

25. E. Boix, A. Picó, R. Pinedo, I. Aranda, K. Kovacs, Ectopic growth hormone-releasing hormone secretion by thymic carcinoid tumour. Clin. Endocrinol. (Oxf) 57(1), 131-134 (2002). https:// doi.org/10.1046/j.1365-2265.2002.01535.x

26. A.J Seabrook, J.E. Harris, S.B. Velosa, E. Kim, A.M. McInerneyLeo, T. Dwight, J.I. Hockings, N.G. Hockings, J. Kirk, P.J. Leo, A.J. Love, C. Luxford, M. Marshall, O. Mete, D.J. Pennisi, M.A. Brown, A.J. Gill, G.I. Hockings, R.J. Clifton-Bligh, E.L. Duncan, Multiple endocrine tumors associated with germline MAX mutations: multiple endocrine neoplasia type 5? J. Clin. Endocrinol. Metab. (2021). https://doi.org/10.1210/clinem/dgaa957

27. R. Correa, P. Salpea, C.A. Stratakis, Carney complex: an update. Eur. J. Endocrinol. 173(4), M85-M97 (2015). https://doi.org/10. 1530/eje-15-0209

28. C.A. Stratakis, L.S. Kirschner, J.A. Carney, Clinical and molecular features of the Carney complex: diagnostic criteria and recommendations for patient evaluation. J. Clin. Endocrinol. Metab. 86(9), 4041-4046 (2001). https://doi.org/10.1210/jcem.86. 9.7903

29. L. Matyakhina, S. Pack, L.S. Kirschner, E. Pak, P. Mannan, J. Jaikumar, S.E. Taymans, F. Sandrini, J.A. Carney, C.A. Stratakis, Chromosome 2 (2p16) abnormalities in Carney complex tumours. J. Med. Genet. 40(4), 268-277 (2003). https://doi.org/10.1136/ jmg.40.4.268

30. N. Tufton, F. Roncaroli, I. Hadjidemetriou, M.N. Dang, J. Dénes, L. Guasti, M. Thom, M. Powell, S.E. Baldeweg, N. Fersht, M. Korbonits, Pituitary carcinoma in a patient with an SDHB mutation. Endocr. Pathol. 28(4), 320-325 (2017). https://doi.org/10. 1007/s12022-017-9474-7

31. P. Xekouki, E. Szarek, P. Bullova, A. Giubellino, M. Quezado, S. A. Mastroyannis, P. Mastorakos, C.A. Wassif, M. Raygada, N. Rentia, L. Dye, A. Cougnoux, D. Koziol, L. Sierra Mde, C. Lyssikatos, E. Belyavskaya, C. Malchoff, J. Moline, C. Eng, L.J. Maher 3rd, K. Pacak, M. Lodish, C.A. Stratakis, Pituitary adenoma with paraganglioma/pheochromocytoma (3PAs) and succinate dehydrogenase defects in humans and mice. J. Clin. Endocrinol. Metab. 100(5), E710-E719 (2015). https://doi.org/10. 1210/jc.2014-4297

32. P. Cambiaso, S. Galassi, M. Palmiero, A. Mastronuzzi, F. Del Bufalo, R. Capolino, A. Cacchione, P.S. Buonuomo, M.V. Gonfiantini, A. Bartuli, M. Cappa, M. Macchiaiolo, Growth hormone excess in children with neurofibromatosis type- 1 and optic glioma. Am. J. Med. Genet. A 173(9), 2353-2358 (2017). https://doi.org/ 10.1002/ajmg.a.38308

33. S. Barry, M. Korbonits, Update on the genetics of pituitary tumors. Endocrinol. Metab. Clin. North Am. 49(3), 433-452 (2020). https://doi.org/10.1016/j.ecl.2020.05.005
34. D. Dworakowska, A.B. Grossman, Are neuroendocrine tumours a feature of tuberous sclerosis? A systematic review. Endocr. Relat. Cancer 16(1), 45-58 (2009). https://doi.org/10.1677/erc-08-0142

35. S.D. Joustra, F. Roelfsema, A.S.P. van Trotsenburg, H.J. Schneider, R.P. Kosilek, H.M. Kroon, J.G. Logan, N.C. Butterfield, X. Zhou, C. Toufaily, B. Bak, M.O. Turgeon, E. Brûlé, F.J. Steyn, M. Gurnell, O. Koulouri, P. Le Tissier, P. Fontanaud, J.H. Duncan Bassett, G.R. Williams, W. Oostdijk, J.M. Wit, A.M. Pereira, N.R. Biermasz, D.J. Bernard, N. Schoenmakers, IGSF1 deficiency results in human and murine somatotrope neurosecretory hyperfunction. J. Clin. Endocrinol. Metab. 105(3), e70-e84 (2020). https://doi.org/10.1210/clinem/dgz093

36. L. Vallar, A. Spada, G. Giannattasio, Altered Gs and adenylate cyclase activity in human GH-secreting pituitary adenomas. Nature 330(6148), 566-568 (1987). https://doi.org/10.1038/330566a0

37. D.M. Carty, R. Harte, R.S. Drummond, R. Ward, K. Magid, D. Collier, M. Owens, M. Korbonits, AIP variant causing familial prolactinoma. Pituitary (2020). https://doi.org/10.1007/s11102020-01085-5

38. M.V. Gordon, D. Varma, C.A. McLean, R.G. Bittar, J.R. Burgess, D.J. Topliss, Metastatic prolactinoma presenting as a cervical spinal cord tumour in multiple endocrine neoplasia type one (MEN-1). Clin. Endocrinol. (Oxf) 66(1), 150-152 (2007). https:// doi.org/10.1111/j.1365-2265.2006.02697.x

39. C. Li, W. Xie, J.S. Rosenblum, J. Zhou, J. Guo, Y. Miao, Y. Shen, H. Wang, L. Gong, M. Li, S. Zhao, S. Cheng, H. Zhu, T. Jiang, S. Ling, F. Wang, H. Zhang, M. Zhang, Y. Qu, Q. Zhang, G. Li, J. Wang, J. Ma, Z. Zhuang, Y. Zhang, Somatic SF3B1 hotspot mutation in prolactinomas. Nat. Commun. 11(1), 2506 (2020). https://doi.org/10.1038/s41467-020-16052-8

40. A.P.Y. Liu, M.M. Kelsey, N. Sabbaghian, S.H. Park, C.L. Deal, A.J. Esbenshade, O. Ploner, A. Peet, H. Traunecker, Y.H.E. Ahmed, M. Zacharin, A. Tiulpakov, A.M. Lapshina, A.W. Walter, P. Dutta, A. Rai, M. Korbonits, L. de Kock, K.E. Nichols, W.D. Foulkes, J.R. Priest, Clinical outcomes and complications of pituitary blastoma. J. Clin. Endocrinol. Metab. 106(2), 351-363 (2021). https://doi.org/10.1210/clinem/dgaa857

41. K.A.P. Schultz, G.M. Williams, J. Kamihara, D.R. Stewart, A.K. Harris, A.J. Bauer, J. Turner, R. Shah, K. Schneider, K.W. Schneider, A.G. Carr, L.A. Harney, S. Baldinger, A.L. Frazier, D. Orbach, D.T. Schneider, D. Malkin, L.P. Dehner, Y.H. Messinger, D.A. Hill, DICER1 and associated conditions: identification of atrisk individuals and recommended surveillance strategies. Clin. Cancer Res. 24(10), 2251-2261 (2018). https://doi.org/10.1158/ 1078-0432.Ccr-17-3089

42. W.F. Simonds, S. Varghese, S.J. Marx, L.K. Nieman, Cushing's syndrome in multiple endocrine neoplasia type 1 . Clin. Endocrinol. (Oxf) 76(3), 379-386 (2012). https://doi.org/10.1111/j.13652265.2011.04220.x

43. F. Chasseloup, N. Pankratz, J. Lane, F.R. Faucz, M.F. Keil, P. Chittiboina, D.M. Kay, T. Hussein Tayeb, C.A. Stratakis, J.L. Mills, L.C. Hernández-Ramírez, Germline CDKN1B loss-offunction variants cause pediatric Cushing's disease with or without an MEN4 phenotype. J. Clin. Endocrinol. Metab. 105(6), 1983-2005 (2020). https://doi.org/10.1210/clinem/dgaa160

44. L.C. Hernández-Ramírez, R. Gam, N. Valdés, M.B. Lodish, N. Pankratz, A. Balsalobre, Y. Gauthier, F.R. Faucz, G. Trivellin, P. Chittiboina, J. Lane, D.M. Kay, A. Dimopoulos, S. Gaillard, M. Neou, J. Bertherat, G. Assié, C. Villa, J.L. Mills, J. Drouin, C.A. Stratakis, Loss-of-function mutations in the CABLES1 gene are a novel cause of Cushing's disease. Endocr. Relat. Cancer 24(8), 379-392 (2017). https://doi.org/10.1530/erc-17-0131

45. D. Bengtsson, P. Joost, C. Aravidis, M. Askmalm Stenmark, A.S. Backman, B. Melin, J. von Salomé, T. Zagoras, S. Gebre-Medhin, P. Burman, Corticotroph pituitary carcinoma in a patient with Lynch syndrome (LS) and pituitary tumors in a nationwide LS 
cohort. J. Clin. Endocrinol. Metab. 102(11), 3928-3932 (2017). https://doi.org/10.1210/jc.2017-01401

46. A. Naziat, N. Karavitaki, R. Thakker, O. Ansorge, G. Sadler, F. Gleeson, T. Cranston, A. McCormack, A.B. Grossman, B. Shine, Confusing genes: a patient with MEN2A and Cushing's disease. Clin. Endocrinol. (Oxf) 78(6), 966-968 (2013). https://doi.org/10. 1111/cen.12072

47. K. Kasturi, L. Fernandes, M. Quezado, M. Eid, L. Marcus, P. Chittiboina, M. Rappaport, C.A. Stratakis, B. Widemann, M. Lodish, Cushing disease in a patient with multiple endocrine neoplasia type 2B. J. Clin. Transl. Endocrinol. Case Rep. 4, 1-4 (2017). https://doi.org/10.1016/j.jecr.2017.02.001

48. M. Reincke, S. Sbiera, A. Hayakawa, M. Theodoropoulou, A. Osswald, F. Beuschlein, T. Meitinger, E. Mizuno-Yamasaki, K. Kawaguchi, Y. Saeki, K. Tanaka, T. Wieland, E. Graf, W. Saeger, C.L. Ronchi, B. Allolio, M. Buchfelder, T.M. Strom, M. Fassnacht, M. Komada, Mutations in the deubiquitinase gene USP8 cause Cushing's disease. Nat. Genet 47(1), 31-38 (2015). https:// doi.org/10.1038/ng.3166

49. I.Q. Wanichi, B.M. de Paula Mariani, F.P. Frassetto, S.A.C. Siqueira, N.R. de Castro Musolino, M.B.C. Cunha-Neto, G. Ochman, V.A.S. Cescato, M.C. Machado, E.B. Trarbach, M.D. Bronstein, M. Fragoso, Cushing's disease due to somatic USP8 mutations: a systematic review and meta-analysis. Pituitary 22(4), 435-442 (2019). https://doi.org/10.1007/s11102-019-00973-9

50. M. Cohen, R. Persky, R. Stegemann, L.C. Hernández-Ramírez, D. Zeltser, M.B. Lodish, A. Chen, M.F. Keil, C. Tatsi, F.R. Faucz, D. A. Buchner, C.A. Stratakis, D. Tiosano, Germline USP8 mutation associated with pediatric cushing disease and other clinical features: a new syndrome. J. Clin. Endocrinol. Metab. 104(10), 4676-4682 (2019). https://doi.org/10.1210/jc.2019-00697

51. E.A. Williamson, P.G. Ince, D. Harrison, P. Kendall-Taylor, P.E. Harris, G-protein mutations in human pituitary adrenocorticotrophic hormone-secreting adenomas. Eur. J. Clin. Invest. 25(2), 128-131 (1995). https://doi.org/10.1111/j.1365-2362.1995. tb01537.x

52. M. Riminucci, M.T. Collins, R. Lala, A. Corsi, P. Matarazzo, P. Gehron Robey, P. Bianco, An R201H activating mutation of the GNAS1 (Gsalpha) gene in a corticotroph pituitary adenoma. Mol. Pathol. 55(1), 58-60 (2002). https://doi.org/10.1136/mp.55.1.58

53. F.W. Kiefer, Y. Winhofer, D. Iacovazzo, M. Korbonits, S. Wolfsberger, E. Knosp, F. Trautinger, R. Höftberger, M. Krebs, A. Luger, A. Gessl, PRKAR1A mutation causing pituitarydependent Cushing disease in a patient with Carney complex. Eur. J. Endocrinol. 177(2), K7-k12 (2017). https://doi.org/10.1530/eje$17-0227$

54. L.C. Hernández-Ramírez, C. Tatsi, M.B. Lodish, F.R. Faucz, N. Pankratz, P. Chittiboina, J. Lane, D.M. Kay, N. Valdés, A. Dimopoulos, J.L. Mills, C.A. Stratakis, Corticotropinoma as a component of Carney complex. J. Endocr. Soc. 1(7), 918-925 (2017). https://doi.org/10.1210/js.2017-00231

55. O. Casar-Borota, H.B. Boldt, B.E. Engström, M.S. Andersen, B. Baussart, D. Bengtsson, K. Berinder, B. Ekman, U. Feldt-Rasmussen, C. Höybye, J.O.L. Jørgensen, A.J. Kolnes, M. Korbonits, A.K. Rasmussen, J.R. Lindsay, P.B. Loughrey, D. Maiter, E. Manojlovic-Gacic, J. Pahnke, P.L. Poliani, V. Popovic, O. Ragnarsson, C. Schalin-Jäntti, D. Scheie, M. Tóth, C. Villa, M. Wirenfeldt, J. Kunicki, P. Burman, Corticotroph aggressive pituitary tumours and carcinomas frequently harbour ATRX mutations. J. Clin. Endocrinol. Metab. (2020). https://doi.org/10. 1210/clinem/dgaa749

56. C.E. Stiles, M. Korbonits, in Familial Isolated Pituitary Adenoma, ed. by K.R. Feingold, B. Anawalt, A. Boyce, G. Chrousos, W.W. de Herder, K. Dungan, A. Grossman, J.M. Hershman, H.J. Hofland, G. Kaltsas, C. Koch, P. Kopp, M. Korbonits, R. McLachlan, J.E. Morley, M. New, J. Purnell, F. Singer, C.A. Stratakis, D.L.
Trence, D.P. Wilson. Endotext. MDText.com, Inc.Copyright (C) 2000-2020, MDText.com, Inc., South Dartmouth (MA), 2000.

57. T.J. Taylor, S.S. Donlon, A.E. Bale, R.C. Smallridge, T.B. Francis, R.S. Christensen, K.D. Burma, Treatment of a thyrotropinoma with octreotide-LAR in a patient with multiple endocrine neoplasia-1. Thyroid 10(11), 1001-1007 (2000). https://doi. org/10.1089/thy.2000.10.1001

58. B.W. Scheithauer, K. Kovacs, V. Nose, M. Lombardero, Y.R. Osamura, R.V. Lloyd, E. Horvath, A. Pagenstecher, J.E. Bohl, D. S. Tews, Multiple endocrine neoplasia type 1-associated thyrotropin-producing pituitary carcinoma: report of a probable de novo example. Hum. Pathol. 40(2), 270-278 (2009). https://doi.org/10. 1016/j.humpath.2008.06.013

59. D. Erickson, B. Scheithauer, J. Atkinson, E. Horvath, K. Kovacs, R.V. Lloyd, W.F. Young Jr, Silent subtype 3 pituitary adenoma: a clinicopathologic analysis of the Mayo Clinic experience. Clin. Endocrinol. (Oxf) 71(1), 92-99 (2009). https://doi.org/10.1111/j. 1365-2265.2008.03514.x

60. O. Mete, K. Gomez-Hernandez, W. Kucharczyk, R. Ridout, G. Zadeh, F. Gentili, S. Ezzat, S.L. Asa, Silent subtype 3 pituitary adenomas are not always silent and represent poorly differentiated monomorphous plurihormonal Pit-1 lineage adenomas. Mod. Pathol. 29(2), 131-142 (2016). https://doi.org/10.1038/modpa thol.2015.151

61. J. Trouillas, F. Labat-Moleur, N. Sturm, M. Kujas, M.F. Heymann, D. Figarella-Branger, M. Patey, M. Mazucca, E. Decullier, B. Vergès, O. Chabre, A. Calender, Pituitary tumors and hyperplasia in multiple endocrine neoplasia type 1 syndrome (MEN1): a case-control study in a series of 77 patients versus 2509 nonMEN1 patients. Am. J. Surg. Pathol. 32(4), 534-543 (2008). https://doi.org/10.1097/PAS.0b013e31815ade45

62. S. Ando, N.J. Sarlis, E.H. Oldfield, P.M. Yen, Somatic mutation of TRbeta can cause a defect in negative regulation of TSH in a TSH-secreting pituitary tumor. J. Clin. Endocrinol. Metab. 86(11), 5572-5576 (2001). https://doi.org/10.1210/jcem.86.11.7984

63. X. Teng, T. Jin, G.A. Brent, A. Wu, W. Teng, Z. Shan, A patient with a thyrotropin-secreting microadenoma and resistance to thyroid Hormone (P453T). J. Clin. Endocrinol. Metab. 100(7), 2511-2514 (2015). https://doi.org/10.1210/jc.2014-3994

64. H. Furumoto, H. Ying, G.V. Chandramouli, L. Zhao, R.L. Walker, P.S. Meltzer, M.C. Willingham, S.Y. Cheng, An unliganded thyroid hormone beta receptor activates the cyclin D1/ cyclin-dependent kinase/retinoblastoma/E2F pathway and induces pituitary tumorigenesis. Mol. Cell. Biol. 25(1), 124-135 (2005). https://doi.org/10.1128/mcb.25.1.124-135.2005

65. P. Marques, F. Caimari, L.C. Hernández-Ramírez, D. Collier, D. Iacovazzo, A. Ronaldson, K. Magid, C.T. Lim, K. Stals, S. Ellard, A.B. Grossman, M. Korbonits, Significant benefits of AIP testing and clinical screening in familial isolated and young-onset pituitary tumors. J. Clin. Endocrinol. Metab. 105(6), e2247-e2260 (2020). https://doi.org/10.1210/clinem/dgaa040

66. T. Cuny, M. Pertuit, M. Sahnoun-Fathallah, A. Daly, G. Occhi, M. F. Odou, A. Tabarin, M.L. Nunes, B. Delemer, V. Rohmer, R. Desailloud, V. Kerlan, O. Chabre, J.L. Sadoul, M. Cogne, P. Caron, C. Cortet-Rudelli, A. Lienhardt, I. Raingeard, A.M. Guedj, T. Brue, A. Beckers, G. Weryha, A. Enjalbert, A. Barlier, Genetic analysis in young patients with sporadic pituitary macroadenomas: besides AIP don't forget MEN1 genetic analysis. Eur. J. Endocrinol. 168(4), 533-541 (2013). https://doi.org/10.1530/eje-120763

67. M. Korbonits, H. Storr, A.V. Kumar, Familial pituitary adenomas - who should be tested for AIP mutations? Clin. Endocrinol. (Oxf) 77(3), 351-356 (2012). https://doi.org/10.1111/j.13652265.2012.04445.x

68. R.V. Thakker, P.J. Newey, G.V. Walls, J. Bilezikian, H. Dralle, P. R. Ebeling, S. Melmed, A. Sakurai, F. Tonelli, M.L. Brandi, 
Clinical practice guidelines for multiple endocrine neoplasia type 1 (MEN1). J. Clin. Endocrinol. Metab. 97(9), 2990-3011 (2012). https://doi.org/10.1210/jc.2012-1230

69. A. Tudorancea, P. François, J. Trouillas, J.P. Cottier, J.J. Girard, M. Jan, B. Gilbert-Dussardier, S. Richard, P. Lecomte, Von Hippel-Lindau disease and aggressive GH-PRL pituitary adenoma in a young boy. Ann. Endocrinol. (Paris) 73(1), 37-42 (2012). https://doi.org/10.1016/j.ando.2011.12.001

70. D. Miljic, S. Pekic, M. Doknic, M. Nikolic-Djurovic, M. Stojanovic, E. Manojlovic-Gacic, M. Korbonits, J. Trouillas, A. Vasiljevic, V. Popovic, M. Petakov, Changes in pituitary tumour biology and behaviour in FIPA patient with GH secreting aggressive pituitary macro adenoma. Endocrine Abstracts 49, EP954 (2017). https://doi.org/10.1530/endoabs.49.EP954

71. S. Tigas, P.V. Carroll, R. Jones, E. Bingham, D. Russell-Jones, M. Powell, I.N. Scobie, Simultaneous Cushing's disease and tuberous sclerosis; a potential role for TSC in pituitary ontogeny. Clin.
Endocrinol. (Oxf) 63(6), 694-695 (2005). https://doi.org/10.1111/ j.1365-2265.2005.02374.x

72. R. Nandagopal, A. Vortmeyer, E.H. Oldfield, M.F. Keil, C.A. Stratakis, Cushing's syndrome due to a pituitary corticotropinoma in a child with tuberous sclerosis: an association or a coincidence? Clin. Endocrinol. (Oxf) 67(4), 639-641 (2007). https://doi.org/10. 1111/j.1365-2265.2007.02941.x

73. S. Uraki, H. Ariyasu, A. Doi, H. Furuta, M. Nishi, K. Sugano, N. Inoshita, N. Nakao, S. Yamada, T. Akamizu, Atypical pituitary adenoma with MEN1 somatic mutation associated with abnormalities of DNA mismatch repair genes; MLH1 germline mutation and MSH6 somatic mutation. Endocr. J. 64(9), 895-906 (2017). https://doi.org/10.1507/endocrj.EJ17-0036

74. M.R. Voisin, J.P. Almeida, B. Perez-Ordonez, G. Zadeh, Recurrent undifferentiated carcinoma of the sella in a patient with Lynch syndrome. World Neurosurg. 132, 219-222 (2019). https://doi. org/10.1016/j.wneu.2019.08.180 